Article

\title{
Environmental Education: Reflecting on Application of Environmental Attitudes Measuring Scale in Higher Education Students
}

\author{
Helen Kopnina ${ }^{1,2, *}$ and Andreea Cocis ${ }^{2}$ \\ 1 Institute Cultural Anthropology and Development Sociology, Faculty Social and Behavioural Sciences, \\ Leiden University, Wassenaarseweg 52, 2300 RB Leiden, The Netherlands \\ 2 International Business Management Studies, The Hague University of Applied Science, \\ Johanna Westerdijkplein 75, 2521 EN Den Haag, The Netherlands; A.Cocis@student.hhs.nl \\ * Correspondence: h.n.kopnina@fsw.leidenuniv.nl or h.kopnina@hhs.nl; Tel.: +31-645-584-957
}

Received: 26 June 2017; Accepted: 21 July 2017; Published: 14 August 2017

\begin{abstract}
The Ecocentric and Anthropocentric Attitudes toward the Sustainable Development (EAATSD) scale measures environmental concern in relation to sustainable development. This article will discuss how this scale was tested with three groups of Dutch higher education students. Findings demonstrate that anthropocentric and ecocentric values are independent of the students' chosen course of study, suggesting that students attracted by the 'sustainable development' course title do not necessarily associate 'sustainability' with ecocentric aims. This article discusses why ecocentric values are beneficial to the objective of a sustainable society and proposes ways forward in which these values can be enhanced in learners.
\end{abstract}

Keywords: anthropocentrism; ecocentrism; environmental attitudes; sustainable development

\section{Introduction}

\subsection{Environmental Values in 'Sustainability'}

Greater interest in environmental education (EE) has emerged as even short educational programs that involved ecocentric values development proved to stimulate environmental awareness in children [1,2] and college students [3-6]. Studies of environmental views by school and college students come from a wide variety of fields including sociology, social psychology, pedagogical studies, and the life sciences (e.g., [7-9]). Social psychologists have applied knowledge from the research literatures on attitudes [10,11], conversion of environmental intentions to environmental behaviors [12], behavior-based environmental attitudes [13], moral reasoning and persuasion [14,15], reasoning about environmental dilemmas [16], commitment [17], normative influence [18], and incentives [19]. A number of environmental attitudes and behavior measuring scales were developed, measuring behavioral commitments, affective states, and knowledge [20], such as the Environmental Concern Scale [21]. Based on these scales, the New Ecological Paradigm (NEP) scale for measuring environmental attitudes [22] became a widely used measure of people's shifting worldviews from a human-dominant view to an ecological one. While the NEP scale has been applied in cross-cultural studies [23,24], it was not always found to be cross-culturally applicable (e.g., [25,26]). Very few of these studies explicitly measure ecocentric values, with the exception of the Ecocentric and Anthropocentric Attitudes toward the Sustainable Development (EAATSD) scale [27]. 
The Ecocentric and Anthropocentric Attitudes toward the Sustainable Development (EAATSD) scale is based on Ecocentric and Anthropocentric Attitudes towards the Environment (EAATE) scale [28]. The EAATSD scale adapted EAATE to sustainable development. EAATSD scale was used in studies related to environmental education (EE) and education for sustainable development (ESD) (e.g., [29-32]), teachers' conceptions of the environment [33] and other studies that apply environmental values in educational contexts. A ecocentric perspective that derives from land ethics [34] and deep ecology [35] refers to an ethical position that the integrity of an ecosystem is essential to human and environmental sustainability. Earlier, EE was often instructed by the ecocentric position as exemplified by The Belgrade Charter-A Global Framework for Environmental Education developed by UNESCO and UNEP in 1976. EE refers to programs that take place in schools or protected nature areas, promoting environmental awareness, encouraging sustainable behaviors, and disseminating specific kinds of knowledge about the environment. ESD shifts the focus away from problems with environmental degradation to the inclusion of social issues and economic development. ESD refers to programs developed after the introduction of the Sustainable Development agenda by the so-called Brundlandt report in 1987. The UN Conference on Environment and Development (1992) produced a key set of plans termed Agenda 21, expanding upon those formulated in the Brundlandt report and aimed at achieving sustainable development. Agenda 21 assigned education a central role: "Education is critical for promoting sustainable development and improving the capacity of the people to address environment and development issues."

Ecocentric education includes conservation education (e.g., [36,37]), education for deep ecology (e.g., [38,39]), post-humanist education (e.g., [40]), animal rights (e.g., [41,42]), and animal welfare education (e.g., [43]). These types of EE focus on unity between environmental ethics and sustainability $[4-6,27,44-73]$. These types of education will collectively be referred to as ecocentric education.

In the context of business education, as well as liberal arts, a number of concrete programs aimed to enhance ecocentric values have been reported $[50,51,62,63,65]$. This article will draw recommendations in relation to EE and ESD by discussing case studies and ecocentric values in education.

\subsection{Ecocentric Perspective on Sustainable Development}

Critics have emphasized that promoting economic development is not likely to address the root causes of poverty, namely the transnational politics of competition in global markets and industrial capital $[74,75]$. Simultaneously, sustainable development rhetoric tends to privilege human welfare over concerns with the environment $[76,77]$. This prioritizing of economic objectives negates the very chance of other species' evolutionary unfolding [78,79] and ecological justice [80,81].

The studies of environmental values indicate that respondents that are more ecocentric are more prone to pro-environmental and sustainable action, including commitment to pay $[28,82]$. Gifford (2011) [83], for example, notes that although many individuals are engaged in some ameliorative action to address climate change, they are hindered by a number of psychological barriers, such as ideological worldviews that preclude pro-environmental attitudes and behavior.

Since humans depend completely on earth's ecosystems and their services, such as "clean air, food, water, climate regulation, spiritual fulfillment, and aesthetic enjoyment" (e.g., [84] (p. 224)), there are material, spiritual, educational, recreational benefits to nature protection (e.g., [85]). There is also evidence that high interdependency of species is a precondition for sustaining human welfare (e.g., [86]). Therefore, conversion theory [87] postulates that preservation of nature for the sake of humanity is most effective. At present, much of ESD is based on the assumption that social, economic and environmental interests do indeed converge, and that plural ethical perspectives in education are desirable (e.g., [88-91]). However, while an anthropocentric motivation can produce environmentally positive outcomes in situations where both humans and nonhumans are negatively affected, as in cases of pollution or climate change, anthropocentrism is not enough to protect natural elements that have no utilitarian value $[77,81,92-99]$. Critical scholars have argued that mainstream ESD ignores the 
urgency of environmental problems through the discursive politics of neoliberal ideology of equitable economic growth (e.g., [100-104]). While the ecocentric position recognizes congruity between human and environmental interests, it also recognizes intrinsic value of nature (e.g., [105]). While species extinctions may indirectly affect human welfare, the loss of some biodiversity does not affect humanity in any negative way-yet it has an existential effect upon nonhumans $[79,106]$.

Thus, anthropocentric position does not protect "left over" species, nor safeguard animal welfare [96,107-109]. In order to safeguard environmental sustainability for humans and nonhumans alike, the environmental predicament requires commitment, as well as urgent measures combining care for individual animals, species, habitats, and people $[110,111]$. Some EE/ESD scholars and practitioners have succeeded not just in raising environmental awareness among their students and scholastic audiences, but also in positively influencing environmentally sustainable behavior, and they have done so via the types of education that this research seeks to better comprehend. Yet, there is no research into the prevalence, characteristics, and efficacy of ecocentric education that places environmental protection as the cornerstone of sustainability. Nor are there specific assessments of the programs that use environmental integrity as a starting point of sustainable economy, such as Cradle to Cradle [112] or circular economy [113]. Applications of these theories in education were discussed by Kopnina \& Blewitt (2014) [114] but no over-arching inventory of ecocentric education has yet been made.

At present EE/ESD research is dominated by uniform, generic indicators and embedded in an anthropocentric perspective. This is problematic because the studies of environmental values indicate that people with ecocentric orientation are more likely to act upon their values in order to protect the environment (e.g., $[82,115,116])$ since anthropocentrism as one of the main drivers of the current ecological crisis (e.g., [117]).

Critical theorists have pointed out that there are some salient paradoxes present in ESD that may in fact undermine the original aims of EE (e.g., [59,66,118,119]). In the article The turn away from 'environment' in environmental education [66] it was argued that environmental sustainability in EE and ESD (further referred to as EE/ESD) is becoming subservient to paradoxical and largely anthropocentric agendas of sustainable development. Ad hoc studies evaluating efficacy of EE/ESD use social, economic and environmental indicators without dealing with these paradoxes. Aside from Chawla and Cushing's (2007) [120] study of strategic environmental learning, and the growing body of research on varieties of EE/ESD, little research engages with the efficacy of EE/ESD in bringing about social change in educating for the environment. There are no consistent studies providing evidence of how EE and/or ESD help to develop a population 'that is aware of, and concerned about, the environment and its associated problems' [121].

\subsection{Ecocentric and Anthropocentric Values in Education}

Initially, EE was intended "to develop a world population that is aware of, and concerned about, the environment and its associated problems, and which has the knowledge, skills, attitudes, motivations and commitment to work individually and collectively toward solutions of current problems and the prevention of new ones" [121]. The intended result of these programmes was social change towards a more environmentally sustainable society, assuming that social and economic sustainability is dependent on environmental integrity. At the time, ecocentric education was found to be best suited for this aim as it enables radical and disruptive change.

However, following decades have witnessed a reversal of this conviction, with anthropocentric motivations and agendas taking central stage. Since the completion of the Decade of Education for Sustainable Development (2005-2014) [122], the emergence of education for sustainable development (ESD) has been hailed as a progressive transition in the field. 
The relationship between EE and ESD is explored in publications of Canadian Journal of Environmental Education (e.g., [123]); Journal of Curriculum Studies (e.g., [118]) and The Journal of Environmental Education (e.g., [104,124]). Some authors argue that ESD is not likely to replace EE but become one of its goals (e.g., $[125,126])$ that ESD is a dominant perspective of EE [123] or that EE has in fact become ESD (e.g., [127]). Similarly, distinctions were drawn between ESD, sustainable development education (SDE), and 'education for sustainability' (EfS) (for historical overview see [128] and [129], for recent debates see $[6,130,131])$. Entire editions of Environmental Education Research journal were devoted to ESD, such as, Denmark and Sweden (Volume 16, Number 1, 2010), Iceland (Volume 17, Number 3, 2011), and The Benelux (Forthcoming in 2017).

\section{Materials and Methods}

This confirmation study, following the pilot conducted in 2013, involved two student populations: students of International Business at The Hague University of Applied Science who followed the required course Business Ethics and Sustainability, with 42 participating students; and Leiden University College (LUC) students of the elective course Environment and Development, with 18 participants. All student populations consisted of international students in their second and third year of study, between the ages of 20 and 24, with a roughly equal male to female ratio. At The Hague University, 49 students (out of total of 270 of the student population) were selected from different elective minors to ensure heterogeneity of responses. Among these, 33 students chose the Sustainable Business minor and 16 students chose other minors.

The confirmation study took place between January and March 2016. Students were asked to rate a degree of agreement on the scale from one to five. All students were asked to complete the scale without initial discussion of what the scale was about, or about ecocentric values. Completion of the scale by the students was accompanied by an in-class discussion about perceptions and attitudes toward the relationship of humans to nature.

\section{Theory/Calculation}

\section{Results}

As reported in Kopnina and Cocis (2017) [132], which discuss detailed results of this study, calculations included of frequency, mean, standard deviation and Chi-square, using simple or cross tabs. Kopnina and Cocis (2017) [132] have concluded that there is a large variation between individual students but not so much between the groups. The group statistics are presented in Tables 1 and 2 . Detailed SPSS results are shown in the Supplementary Materials.

The in-class discussion has revealed that student perceptions of 'sustainability' and particularly 'sustainable development' are not necessarily linked to environmental problems. Social and economic sustainability were sometimes discussed as cornerstones of sustainability, without the realization that neither long-term poverty alleviation or general human well-being and indeed financial stability are dependent on the availability of natural resources. Some of the students thought that social justice and economic equality were more important than environmental integrity. It needs to be noted that after instruction in critical thinking and discussion of select literature, films, and case studies, students' perceptions were noted to shift towards a more ecocentric world-view (for more discussion of teaching students about paradoxes of sustainability see [6]). 
Table 1. Group statistics.

\begin{tabular}{|c|c|c|c|c|c|}
\hline & Minor & $\mathbf{N}$ & Mean & Standard Deviation & Standard Error Mean \\
\hline \multirow{2}{*}{ Environment Threat } & Sustainable Business & 32 & 20.56 & 1.243 & 0.220 \\
\hline & Other Minor & 16 & 20.69 & 1.302 & 0.326 \\
\hline \multirow{2}{*}{ Overpopulation } & Sustainable Business & 33 & 3.42 & 1.173 & 0.204 \\
\hline & Other Minor & 16 & 3.06 & 1.124 & 0.281 \\
\hline \multirow{2}{*}{ Loss of Rain Forrest } & Sustainable Business & 33 & 3.09 & 1.011 & 0.176 \\
\hline & Other Minor & 16 & 2.69 & 1.014 & 0.254 \\
\hline \multirow{2}{*}{$\begin{array}{l}\text { Forest Cleared for } \\
\text { Agriculture }\end{array}$} & Sustainable Business & 33 & 3.09 & 1.128 & 0.196 \\
\hline & Other Minor & 15 & 2.73 & 1.387 & 0.358 \\
\hline \multirow{2}{*}{ Conservationists } & Sustainable Business & 32 & 2.63 & 1.070 & 0.189 \\
\hline & Other Minor & 16 & 2.81 & 1.047 & 0.262 \\
\hline \multirow{2}{*}{ Problem of Depletion } & Sustainable Business & 32 & 2.34 & 1.125 & 0.199 \\
\hline & Other Minor & 16 & 2.44 & 0.892 & 0.223 \\
\hline \multirow{2}{*}{ Environmental Issues } & Sustainable Business & 32 & 2.72 & 1.276 & 0.226 \\
\hline & Other Minor & 16 & 2.56 & 1.094 & 0.273 \\
\hline \multirow{2}{*}{ Drilling for Oil } & Sustainable Business & 32 & 3.34 & 1.208 & 0.214 \\
\hline & Other Minor & 16 & 3.56 & 0.964 & 0.241 \\
\hline \multirow{2}{*}{ Deforestation } & Sustainable Business & 33 & 3.73 & 1.206 & 0.210 \\
\hline & Other Minor & 15 & 3.07 & 1.100 & 0.284 \\
\hline \multirow{2}{*}{$\begin{array}{c}\text { Don't Care about } \\
\text { Environment Problems }\end{array}$} & Sustainable Business & 33 & 1.67 & 1.109 & 0.193 \\
\hline & Other Minor & 16 & 1.75 & 1.291 & 0.323 \\
\hline \multirow{2}{*}{ Lakes Andrivers Clean } & Sustainable Business & 33 & 3.33 & 1.164 & 0.203 \\
\hline & Other Minor & 16 & 2.69 & 1.195 & 0.299 \\
\hline \multirow{2}{*}{$\begin{array}{l}\text { Natural Environments } \\
\text { Destroyed }\end{array}$} & Sustainable Business & 33 & 4.00 & 0.968 & 0.169 \\
\hline & Other Minor & 16 & 3.69 & 1.401 & 0.350 \\
\hline \multirow{2}{*}{ Human Survival } & Sustainable Business & 33 & 3.21 & 0.992 & 0.173 \\
\hline & Other Minor & 15 & 3.27 & 0.961 & 0.248 \\
\hline \multirow{2}{*}{ Recycling } & Sustainable Business & 33 & 2.67 & 1.164 & 0.203 \\
\hline & Other Minor & 16 & 2.88 & 1.258 & 0.315 \\
\hline \multirow{2}{*}{ Contribute to Humans } & Sustainable Business & 33 & 3.91 & 0.879 & 0.153 \\
\hline & Other Minor & 16 & 3.44 & 0629 & 0.157 \\
\hline \multirow{2}{*}{ Conservation } & Sustainable Business & 33 & 2.94 & 0.966 & 0.168 \\
\hline & Other Minor & 15 & 2.27 & 1.033 & 0.267 \\
\hline \multirow{2}{*}{$\begin{array}{l}\text { Valuable Forits Own } \\
\text { Sake }\end{array}$} & Sustainable Business & 32 & 3.28 & 1.301 & 0.230 \\
\hline & Other Minor & 16 & 2.75 & 1.065 & 0.266 \\
\hline \multirow{2}{*}{$\begin{array}{l}\text { High Standards of } \\
\text { Living }\end{array}$} & Sustainable Business & 33 & 3.79 & 1.053 & 0.183 \\
\hline & Other Minor & 16 & 3.75 & 0.931 & 0.233 \\
\hline \multirow{2}{*}{ Plants and Animals } & Sustainable Business & 33 & 3.91 & 0.947 & 0.165 \\
\hline & Other Minor & 16 & 4.00 & 0.632 & 0.158 \\
\hline \multirow{2}{*}{ Land Development } & Sustainable Business & 33 & 3.39 & 0.998 & 0.174 \\
\hline & Other Minor & 16 & 3.38 & 1.025 & 0.256 \\
\hline \multirow{2}{*}{ Animal Testing } & Sustainable Business & 33 & 3.06 & 1.029 & 0.179 \\
\hline & Other Minor & 16 & 3.19 & 1.377 & 0.344 \\
\hline \multirow{2}{*}{ Animal Rights } & Sustainable Business & 33 & 3.09 & 1.128 & 0.196 \\
\hline & Other Minor & 16 & 3.44 & 1.365 & 0.341 \\
\hline
\end{tabular}


Table 2. 2016 Study.

\begin{tabular}{lccccccccc}
\hline & \multicolumn{9}{c}{ Minor } \\
\cline { 2 - 10 } & \multicolumn{3}{c}{ E\&D } & \multicolumn{3}{c}{ BE\&S } & \multicolumn{3}{c}{ Total } \\
\cline { 2 - 10 } & Mean & $\mathbf{N}$ & Stand Deviation & Mean & $\mathbf{N}$ & Stand Deviation & Mean & N & Stand Deviation \\
\hline EASTSD1 & 3.9444 & 18 & 0.93760 & 3.7619 & 42 & 0.90553 & 3.8167 & 60 & 0.91117 \\
EASTSD2 & 1.1667 & 18 & 0.38348 & 2.3333 & 42 & 1.05152 & 1.9833 & 60 & 1.04948 \\
EASTSD3 & 2.2778 & 18 & 0.89479 & 3.0476 & 42 & 1.08093 & 2.8167 & 60 & 1.08130 \\
EASTSD4 & 3.8889 & 18 & 0.67640 & 3.3333 & 42 & 0.92833 & 3.5000 & 60 & 0.89253 \\
EASTSD5 & 2.0588 & 17 & 1.34493 & 2.6341 & 41 & 0.88758 & 2.4655 & 58 & 1.06319 \\
EASTSD6 & 1.3529 & 17 & 0.86177 & 1.9286 & 42 & 0.89423 & 1.7627 & 59 & 0.91612 \\
EASTSD7 & 1.7778 & 18 & 1.16597 & 2.5714 & 42 & 0.85946 & 2.3333 & 60 & 1.01958 \\
EASTSD8 & 2.2778 & 18 & 1.36363 & 3.0000 & 42 & 0.85540 & 2.7833 & 60 & 1.07501 \\
EASTSD9 & 3.5556 & 18 & 0.98352 & 3.5750 & 40 & 1.10680 & 3.5690 & 58 & 1.06148 \\
EASTSD10 & 1.1667 & 18 & 0.38348 & 1.4048 & 42 & 0.58683 & 1.3333 & 60 & 0.54202 \\
EASTSD11 & 2.7778 & 18 & 1.21537 & 3.3333 & 42 & 1.07446 & 3.1667 & 60 & 1.13745 \\
EASTSD12 & 4.1667 & 18 & 1.20049 & 3.7143 & 42 & 1.17465 & 3.8500 & 60 & 1.19071 \\
EASTSD13 & 3.0556 & 18 & 0.93760 & 3.2857 & 42 & 0.96993 & 3.2167 & 60 & 0.95831 \\
EASTSD14 & 2.2778 & 18 & 0.75190 & 2.6190 & 42 & 1.03482 & 2.5167 & 60 & 0.96536 \\
EASTSD15 & 3.5000 & 18 & 0.70711 & 3.6429 & 42 & 1.05510 & 3.6000 & 60 & 0.96023 \\
EASTSD16 & 1.9444 & 18 & 0.72536 & 2.5238 & 42 & 0.63392 & 2.3500 & 60 & 0.70890 \\
EASTSD17 & 4.2778 & 18 & 0.82644 & 3.5952 & 42 & 1.14890 & 3.8000 & 60 & 1.10162 \\
EASTSD18 & 3.0556 & 18 & 1.10997 & 3.3659 & 41 & 1.01873 & 3.2712 & 59 & 1.04767 \\
EASTSD19 & 4.0000 & 18 & 0.90749 & 3.7381 & 42 & 0.88509 & 3.8167 & 60 & 0.89237 \\
EASTSD20 & 2.4444 & 18 & 0.92178 & 3.4762 & 42 & 1.01784 & 3.1667 & 60 & 1.09183 \\
EASTSD21 & 2.5556 & 18 & 1.14903 & 2.6905 & 42 & 1.19935 & 2.6500 & 60 & 1.17639 \\
EASTSD22 & 2.9444 & 18 & 1.05564 & 3.0952 & 42 & 1.37592 & 3.0500 & 60 & 1.28122 \\
\hline
\end{tabular}

\section{Reflection on the Study}

The hypothesis formed in this comparative study was that business students might be less ecocentric then environmental sustainability course students. However, the findings have revealed that both groups exhibit individual differences in environmental attitudes, but little difference between groups. Thus, ecocentric orientation does not necessarily correspond with the choice of course. Students from The Hague University and Leiden University who choose the Sustainable Busness or Environment \&Development courses prioritize anthropocentric concerns in more or less equal measure to other business students. Generally, it appeared that all students tend to be more ecocentric then anthropocentric, with individual differences in ecocentric and anthropocentric orientations independent of the students' choice of a minor. As reported by Kopnina and Cocis (2017) [132], the chi-square analysis revealed that the assumption of the non-dependent variables is confirmed by looking at the likelihood ratios, with ecocentric and anthropocentric values not related. This suggests that the students who have chosen the course on sustainability do not necessarily think of sustainability as being primarily environment-focused, but also related to social and economic aspects of sustainable development'. As discussed in the Introduction, while sustainable development rhetoric does indeed include and even privilege social and economic aspects of sustainability, it tends to downplay the fundamental role of environmental integrity that supports both social and economic interests, as well as ignores the ethical questions associated with ecological justice. Further implication of this is that if the educator wants to develop an ecocentric orientation in students, self-selection of choosing (or not) 'sustainability' courses does not seem to be an obstacle as all students in the present sample seem potentially open to ecocentric values, with individual differences between them.

This is confirmed by in-class discussions that occurred after the scale was completed. The discussion involved the instructor's assignment asking students to reflect on readings related to trade-offs between economic growth and ecological integrity. These discussions have led to shifting student perceptions towards a more inclusive ecocentric world-view-which could admittedly be the result of the students wanting to comply to teacher's expectations, but could also have resulted from indeed a more critical $\mathrm{a}=$ but also compassionate understanding of environmental problems. Full 
literature list and other didactic strategies used by instructor in these courses are discussed in Kopnina 2017 [6].

\section{Discussion}

The relatively uniform results across different courses need to be related to a larger context of sustainability. As mentioned in the introduction, sustainability rhetoric is intertwined with sustainable development that seeks to combine social, economic and environmental objectives $[40,75]$. The EAATSD scale and discussions reported in this article were taken at the start of the course, before the students were exposed to instruction, critical literature and discussions geared towards a more complex understanding of environmental problems and their causes, including discussion of anthropocentric word-views. Understanding of the paradoxes and bottlenecks of sustainable development (an attempt to decouple poverty alleviation from resource consumption) as well as ethical deficiency of favoring one-species perspective (anthropocentrism) is likely to develop after the information (cognitive aspects) has 'sunk in'. This 'sinking' is not likely to happen immediately after the course as it involves deeper alteration in cognitive and affective attitudes have further evolved through continuous learning. This continuous learning is supported by both what students have learned in class and future events in their professional lives.

As discussed in the Introduction, while pragmatist environmental ethics postulates that the intrinsic values have little practical value $[87,133]$, ecocentric ethics argued that the intrinsic value discourse is to environmental policy what the human rights discourse has been to social reform movements [134]. Basically, it is argued that without acknowledging the intrinsic value, the rights and welfare of nonhuman nature that are not functionally useful to human welfare are likely to be continuously ignored [135]. Essentially, anthropocentric orientations make a portion of biological diversity expendable and ignore animal welfare concerns, because no negative side effects for people ensue $[77,78]$.

Presently, a large part of 'sustainability' education is dominated by social and economic concerns, placing environmental protection, at best, as one of many possible objectives [101]. ESD often conflates social and economic sustainability with environmental sustainability, resulting in mutually exclusive objectives [75]. While one of the key objectives of sustainable development is alleviating poverty, it is unclear how this objective can be decoupled from increase in the consumption of natural resources, which in turn is likely to exacerbate social unrest and economic competition and inequality. If an alternative path to economic development cannot be found, the planet is not likely to sustain present and future generations in the long terms $[76,114,136]$. Without fundamentally altering the unsustainable production system, adapting existing production methods in developing countries is likely to exacerbate sustainability challenges and worsen the economic conditions due to competition for resources [137]. Yet, as demonstrated by the case studies above, students that choose 'sustainability' courses do not necessarily see the environment as a foundation that makes social and economic sustainability possible. Thus, further research, as well as teaching practice that explicitly focuses on explaining why ecocentrism provides a distinct and better path for sustainability, is necessary [117].

Besides EE/ESD evaluations in country-specific or program-specific contexts (e.g., [138-140]) the overarching research examining the efficacy of EE/ESD in bringing about environmental sustainability is lacking. The efficacy in this context involves success in promoting awareness of environmental problems and encouraging environmentally sustainable behaviors, as well as developing specific skills and competencies necessary for building a circular economy [112,113]. At the moment, ecocentric EE/ESD is still marginal within educational institutions, policy-making and social scientists. Assuming that a very significant part of 'greening' happens in the educational sector, the implicit application of this research is 'learning from comparison' from 'best practices'. 


\section{Conclusions}

Spannring (2016) [110] (p. 12) has pointed out a number of ways in which nonhumans can be addressed in education, calling for a serious and sustained attention to anthropocentrism and speciesism. Indeed, this article fully supports this call. The appropriateness and socio-cultural sensitivity [141] of disparate components of educational policy can then instruct the design of ecocentric EE/ESD programs. The follow-up research will draw on distinctions between the goals of environmental education 'in, 'about' or 'for' the environment, with explicit focus on ecological values that have been marginalized in mainstream EE/ESD. Follow-up research can then address the following questions: What is the prevalence and characteristics of EE/ESD, and especially ecocentric education? Does EE/ESD positively influence environmental knowledge and attitudes in school children and help develop competencies and skills necessary for transition to a sustainable society in students of higher education? What are the most effective forms of EE/ESD taking environmental sustainability as an ultimate goal? How can context-specific studies of EE/ESD contribute to the scholarship of social change that contributes to environmental sustainability?

Administration of the EAATSD scale and discussion of issues embedded in (environmental) ethics in education The expected societal and economic consequences of this research will be development, stimulation, maintenance and monitoring of successful programs and their adaptation in the wider international context. Understanding how complex variables such as national and institutional context, ideology and ethics (e.g., ecocentric orientation) and pedagogical skills (e.g., didactic qualities) can be supported to ensure a sustainable future, represents a high-reward objective. Subsequent research needs to focus on nationally contextualized studies on the nexus of education, environment, and sustainable future by examining how a wide range of educational programs have influenced the students' worldview and raised particular moral concerns in relation to the environment and our common future.

Supplementary Materials: The following are available online at www.mdpi.com/2227-7102/7/3/69/s1. Table S1: Report, Table S2: EAATSD2 * EAATSD4 Crosstabulation, Table S3: Chi-Square Tests, Table S4: EAATSD6 * EAATSD12 Crosstabulation, Table S5: Chi-Square Tests, Table S6: EAATSD16 * EAATSD19 Crosstabulation, Table S7: Chi-Square Tests, Table S8: EAATSD3 * EAATSD9 Crosstabulation, Table S9: Chi-Square Tests.

Author Contributions: Helen Kopnina wrote the main text, Andreea Cocis did the SPSS analysis.

Conflicts of Interest: The authors declare no conflict of interest.

\section{References}

1. Manoli, C.C.; Johnson, B.; Dunlap, R.E. Assessing children's environmental worldviews: Modifying and validating the New Ecological Paradigm Scale for use with children. J. Environ. Educ. 2007, 38, 3-13. [CrossRef]

2. Sanera, M.; Shaw, J. Facts, Not Fear: Teaching Children about the Environment; Regnery: Washington, DC, USA, 1996.

3. Rideout, B.E. The effect of a brief environmental problems module on endorsement of the New Ecological Paradigm in college students. J. Environ. Educ. 2005, 37, 3-11. [CrossRef]

4. Kopnina, H. If a Tree Falls: Business students' reflections on environmentalism. Int. J. Environ. Sustain. Dev. 2014, 8, 311-329. [CrossRef]

5. Kopnina, H. If a Tree Falls and Everybody Hears the Sound: Teaching deep ecology to business students. J. Educ. Sustain. Dev. 2015, 9, 101-116. [CrossRef]

6. Kopnina, H. Teaching Sustainable Development Goals in The Netherlands: A Critical Approach. EER 2017. Available online: http:/ / www.tandfonline.com/doi/full/10.1080/13504622.2017.1303819 (accessed on 9 August 2017). [CrossRef]

7. Eagles, P.F.J.; Demare, R. Factors influencing children's environmental attitudes. J. Environ. Educ. 1999, 30, 33-37. [CrossRef]

8. Pilgrim, S.E.; Cullen, L.C.; Smith, D.J.; Pretty, J. Ecological knowledge is lost in wealthier communities and countries. Environ. Sci. Technol. 2008, 42, 1004-1009. [CrossRef] [PubMed] 
9. Reid, A. (Ed.) Participation and Learning: Perspectives on Education and the Environment, Health and Sustainability; Springer: New York, NY, USA, 2008.

10. Kellert, S.R. Attitudes, knowledge, and behavior toward wildlife among the industrial superpowers: United States, Japan, and Germany. J. Soc. Issues 1993, 49, 53-69. [CrossRef]

11. Rauwald, K.S.; Moore, C.F. Environmental attitudes as predictors of policy support across three countries. Environ. Behav. 2002, 34, 709-739. [CrossRef]

12. Kaiser, F.G. Conservation behavior. In Encyclopedia of Applied Psychology; Spielberger, C., Ed.; Academic Press: New York, NY, USA, 2004; pp. 473-477.

13. Kaiser, F.G.; Oerke, B.; Bogner, F.X. Behavior-based environmental attitude: Development of an instrument for adolescents. J. Environ. Psychol. 2007, 27, 242-251. [CrossRef]

14. Gonzales, M.H.; Aronson, E.; Costanzo, M.A. Using social cognition and persuasion to promote energy conservation: A quasi-experiment. J. Appl. Soc. Psychol. 1988, 18, 1049-1066. [CrossRef]

15. Kahn, P.H., Jr. The Human Relationship with Nature; MIT Press: Cambridge, MA, USA, 1999.

16. Kahn, P.H., Jr.; Kellert, S.R. (Eds.) Children and Nature; MIT Press: Cambridge, MA, USA, 2002.

17. Pallak, M.S.; Cook, D.A.; Sullivan, J.J. Commitment and energy conservation. In Applied Social Psychology Annual; Bickman, L., Ed.; Sage: Beverly Hills, CA, USA, 1980; pp. 235-253.

18. Aronson, E.; O'Leary, M. The relative effectiveness of models and prompts on energy conservation: A field experiment in a shower room. J. Environ. Syst. 1982, 12, 221-224. [CrossRef]

19. Levitt, L.; Leventhal, G. Litter Reduction: How Effective is the New York State Bottle Bill? Environ. Behav. 1986, 18. Available online: http:/ /journals.sagepub.com/doi/abs/10.1177/0013916586184003 (accessed on 10 August 2017). [CrossRef]

20. Maloney, M.P.; Ward, M.; Braucht, G. A revised scale for the measurement of ecological attitudes and knowledge. Am. Psychol. 1975, 30, 787-790. [CrossRef]

21. Wiegel, R.; Wiegel, J. Environmental Concern. Environ. Behav. 1978, 10, 3-15. [CrossRef]

22. Dunlap, R.E.; van Liere, K.D. The New Environmental Paradigm: A Proposed Measuring Instrument and preliminary results. J. Environ. Educ. 1978, 9, 10-19. [CrossRef]

23. Hawcroft, L.J.; Milfont, T.L. A Meta-Analysis of the Societal Variables Associated with Environmental Attitudes; Victoria University of Wellington: Wellington, New Zealand, 2010.

24. Van Petegem, P.; Blieck, A. The environmental worldview of children: A cross-cultural perspective. Environ. Educ. Res. 2006, 12, 625-635. [CrossRef]

25. Chatterjee, D.P. Oriental disadvantage versus occidental exuberance: Appraising environmental concern in India. Int. Sociol. 2008, 23, 5-33. [CrossRef]

26. Lalonde, R.; Jackson, E.L. The New Environmental Paradigm Scale: Has it outlived its usefulness? J. Environ. Educ. 2002, 33, 28-36. [CrossRef]

27. Kopnina, H. Evaluating Education for Sustainable Development (ESD): Using Ecocentric and Anthropocentric Attitudes toward the Sustainable Development (EAATSD) scale. Environ. Dev. Sustain. 2013, 15, 607-623. [CrossRef]

28. Thompson, G.S.C.; Barton, M.A. Ecocentric and anthropocentric attitudes toward the environment. J. Environ. Psychol. 1994, 14, 149-157. [CrossRef]

29. Besong, F.; Holland, C. The Dispositions, Abilities and Behaviours: Framework for Profiling Learners' Sustainability Competencies in Higher Education. J. Teach. Educ. Sustain. 2015, 17, 5-22. [CrossRef]

30. Cocks, S.; Simpson, S. Anthropocentric and Ecocentric: An Application of Environmental Philosophy to Outdoor Recreation and Environmental Education. J. Exp. Educ. 2015, 38, 1-12. [CrossRef]

31. Kanyimba, A.T.; Richter, B.W.; Raath, S.P. The effectiveness of an environmental management system in selected South African primary schools. J. Clean. Prod. 2014, 66, 479-488. [CrossRef]

32. Wolbring, G.; Burke, B. Reflecting on education for sustainable development through two lenses: Ability studies and disability studies. Sustainability 2013, 5, 2327-2342. [CrossRef]

33. Quinn, F.; Castéra, J.; Clément, P. Teachers' conceptions of the environment: Anthropocentrism, non-anthropocentrism, anthropomorphism and the place of nature. Environ. Educ. Res. 2015, 22, 893-917. [CrossRef]

34. Leopold, A. A Sand County Almanac; Oxford University Press: Oxford, UK, 1949.

35. Naess, A. The shallow and the deep: Long-range ecology movement. A summary. Inquiry 1973, 16, 95-99. [CrossRef] 
36. Goodall, J. Caring for People and Valuing Forests in Africa. In Protecting the Wild: Parks and Wilderness, the Foundation for Conservation; Wuerthner, G., Crist, E., Butler, T., Eds.; The Island Press: Washington, DC, USA, 2015; pp. 21-26.

37. Norris, K.S.; Jacobson, S.K. Content analysis of tropical conservation education programs: Elements of success. J. Environ. Educ. 1998, 30, 38-44. [CrossRef]

38. Glasser, H. Learning Our Way to a Sustainable and Desirable World: Ideas Inspired by Arne Naess and Deep Ecology. In Higher Education and the Challenge of Sustainability: Problematics, Promisei, and Practice; Corcoran, P.B., Wals, A.E.J., Eds.; Springer: Dordrecht, The Netherlands, 2004; pp. 131-148.

39. LaChapelle, D. Educating for Deep Ecology. J. Exp. Educ. 1991, 14, 18-22. [CrossRef]

40. Bonnett, M. Sustainable development, environmental education, and the significance of being in place. Curric. J. 2013, 24, 250-271. [CrossRef]

41. Kopnina, H.; Cherniak, B. Neoliberalism and Justice in Education for Sustainable Development: A call for inclusive pluralism. Environ. Educ. Res. 2016, 22, 827-841. [CrossRef]

42. Ortiz, A. Humane Liberation: Incorporating Animal Rights into Critical Pedagogy. Vt. Connect. 2015, 32, 8-30.

43. Gorski, P.C. Critical Ties: The Animal Rights Awakening of a Social Justice Educator. Available online: http:/ / www.edchange.org/publications/animal-rights-social-justice.pdf (accessed on 11 June 2017).

44. Kopnina, H. Future Scenarios for Sustainability Education. In Envisioning Futures for Environmental and Sustainability Education; Corcoran, P.B., Wals, A., Weakland, J., Eds.; Wageningen Academic Publishers: Wageningen, The Netherlands, 2017.

45. Kopnina, H. Closed loop production models in Environmental Education: Teaching circular economy and the business of subversion. In A Future Beyond Growth: Towards a Steady State Economy; Washington, H., Twomey, P., Eds.; Routledge: New York, NY, USA, 2016.

46. Kopnina, H. Animal cards, supermarket stunts and World Wide Fund for Nature: Exploring the educational value of a business-ENGO partnership for sustainable consumption. J. Consum. Cult. 2016, 16, 926-947. [CrossRef]

47. Kopnina, H. Challenging economic development: The case study of teaching alternative cultural values in business education. J. Integr. Environ. Sci. 2016, 13, 67-84. [CrossRef]

48. Kopnina, H. Of Big Hegemonies and Little Tigers: Ecocentrism and Environmental Justice. Special Issue "On the politics of policy-making for education for sustainable development". J. Environ. Educ. 2016, 47, 132-150. [CrossRef]

49. Kopnina, H.; Gjerris, M. Are some animals more equal than others? Animal Rights and Deep Ecology in environmental education. Can. J. Environ. Educ. 2015, 20, 109-123.

50. Kopnina, H. Metaphors of Nature and Development: Reflection on critical course of sustainable business. Environ. Educ. Res. 2015, 22, 571-589. [CrossRef]

51. Kopnina, H. Neoliberalism, Pluralism, Environment and Education for Sustainability: The call for radical re-orientation. Environ. Dev. 2015, 15, 120-130. [CrossRef]

52. Kopnina, H. Sustainability in Environmental Education: New Strategic Thinking. Environ. Dev. Sustain. 2015, 17, 987-1002. [CrossRef]

53. Kopnina, H.; Meijers, F. Education for sustainable development (ESD): Exploring theoretical and practical challenges. Int. J. Sustain. High. Educ. 2014, 15, 188-207. [CrossRef]

54. Kopnina, H. Debating Ecological Justice: Implications for critical environmental education. Chin. J. Popul. Resour. Environ. 2014, 12, 290-300. [CrossRef]

55. Kopnina, H. Metaphors of Nature and Economic Development: Critical education for sustainable business. Sustainability 2014, 6, 7496-7513. [CrossRef]

56. Kopnina, H. Contesting 'Environment' through the lens of sustainability: Examining Implications for Environmental Education (EE) and Education for Sustainable Development (ESD). Cult. Unbound J. Curr. Cult. Res. 2014, 6, 931-947. [CrossRef]

57. Kopnina, H. Education for Sustainable Development (ESD) as if environment really mattered. Environ. Dev. 2014, 12, 37-46. [CrossRef]

58. Kopnina, H. Future Scenarios and Environmental Education. J. Environ. Educ. 2014, 45, 217-231. [CrossRef] 
59. Kopnina, H. Education for Sustainable Development (ESD): Exploring children's moral reasoning about sustainable development and environment through vignettes. Stud. Educ. Eval. 2014, 41, 124-132. [CrossRef]

60. Kopnina, H. Revisiting Education for Sustainable Development (ESD): Examining anthropocentric bias through the transition of environmental education to ESD. Sustain. Dev. 2014, 22, 73-83. [CrossRef]

61. Kopnina, H. Revisiting the "trans-human" Gestalt: Discussing 'Nature' and 'Development' with Students of Sustainable Business. J. Educ. Sustain. Dev. 2014, 8, 43-63. [CrossRef]

62. Kopnina, H. Future Directions in Environmental Anthropology: Incorporating ethnography of environmental education. In Environmental Anthropology: Future Directions; Kopnina, H., Shoreman-Ouimet, E., Eds.; Routledge: New York, NY, USA, 2013; pp. 77-97.

63. Kopnina, H. Schooling the World: Exploring the critical course on sustainable development through an anthropological lens. Int. J. Educ. Res. 2013, 62, 220-228. [CrossRef]

64. Kopnina, H. An Exploratory Case Study of Dutch Children's Attitudes towards Consumption: Implications for Environmental Education. J. Environ. Educ. 2013, 44, 128-144. [CrossRef]

65. Kopnina, H. (Ed.) Anthropology of Environmental Education; Nova Science Publishers: New York, NY, USA, 2012.

66. Kopnina, H. Education for Sustainable Development (ESD): The way from 'environment' in environmental education? Environ. Educ. Res. 2012, 18, 699-717. [CrossRef]

67. Kopnina, H. "People are no plants, but both need to grow": Qualitative analysis of the New Ecological Paradigm scale for children. Environmentalist 2012, 32, 394-404. [CrossRef]

68. Kopnina, H. Consumption in environmental education: Developing curriculum that addresses Cradle to Cradle principles. Factis Pax J. Peace Educ. Soc. Justice 2011, 5, 374-388.

69. Kopnina, H. Applying the New Ecological Paradigm scale in the case of environmental education: Qualitative analysis of the Ecological world view of Dutch children. Factis Pax J. Peace Educ. Soc. Justice 2011, 5, 362-373.

70. Kopnina, H. What is (responsible) consumption? Discussing environment and consumption with children from different socio-economic backgrounds in the Netherlands. Environmentalist 2011, 31, 216-226. [CrossRef]

71. Kopnina, H. Qualitative Revision of the New Ecological Paradigm (NEP) Scale for children. Int. J. Environ. Res. 2011, 5, 1025-1034.

72. Kopnina, H. Kids and cars: Environmental attitudes in children. Transp. Policy 2011, 18, 573-578. [CrossRef]

73. Kopnina, H. What about that wrapper? Using consumption diaries in green education. In Environmental Anthropology Today; Kopnina, H., Shoreman-Ouimet, E., Eds.; Routledge: New York, NY, USA, 2011; pp. 118-139.

74. Rees, W. What's blocking sustainability? Human nature, cognition, and denial. Sustain. Sci. Pract. Policy 2010, 6, 13-25.

75. Washington, H. Demystifying Sustainability: Towards Real Solutions; Routledge: New York, NY, USA, 2015.

76. Rolston, H. Environmental Ethics for Tomorrow: Sustaining the Biosphere. In Sustainability: Key Issues; Kopnina, H., Shoreman-Ouimet, E., Eds.; Routledge: New York, NY, USA, 2015.

77. Shoreman-Ouimet, E.; Kopnina, H. Conservation and Culture: Beyond Anthropocentrism; Routledge: New York, NY, USA, 2016.

78. Cafaro, P. Three ways to think about the sixth mass extinction. Biol. Conserv. 2015, 192, 387-393. [CrossRef]

79. Crist, E. Abundant Earth and Population. In Life on the Brink: Environmentalists Confront Overpopulation; Philip, C., Eileen, C., Eds.; University of Georgia Press: Athens, GA, USA, 2012; pp. 141-153.

80. Baxter, B. A Theory of Ecological Justice; Routledge: New York, NY, USA, 2005.

81. Kopnina, H. Environmental justice and biospheric egalitarianism: Reflecting on a normative-philosophical view of human-nature relationship. Earth Perspect. 2014, 1, 8. [CrossRef]

82. Kortenkamp, K.V.; Moore, C.F. Ecocentrism and anthropocentrism: Moral reasoning about ecological commons dilemmas. J. Environ. Psychol. 2001, 21, 1-12. [CrossRef]

83. Gifford, R. The dragons of inaction: Psychological barriers that limit climate change mitigation and adaptation. Am. Psychol. 2011, 66, 290. [CrossRef] [PubMed]

84. Tedeschi, P.; Bexell, S.M.; NeSmith, J. Conservation Social Work: The Interconnectedness of Biodiversity Health and Human Resilience. In Ignoring Nature No More: The Case for Compassionate Conservation; Bekoff, M., Ed.; Chicago University Press: Chicago, IL, USA, 2013; pp. 223-236.

85. Miller, B.; Soulé, M.E.; Terborgh, J. 'New conservation' or surrender to development? Anim. Conserv. 2014, 17, 509-515. [CrossRef] 
86. Polasky, S.; Johnson, K.; Keeler, B.; Kovacs, K.; Nelson, E.; Pennington, D.; Plantinga, A.J.; Withey, J. Are investments to promote biodiversity conservation and ecosystem services aligned? Oxf. Rev. Econ. Policy 2012, 28, 139-163. [CrossRef]

87. Norton, B.G. Environmental Ethics and Weak Anthropocentrism. Environ. Ethics 1984, 6, 131-148. [CrossRef]

88. Andrezejewski, J.; Baltodano, M.P.; Symcox, L. Social Justice, Peace, and Environmental Education: Transformative Standards; Routledge: New York, NY, USA, 2009.

89. Cars, M.; West, E.E. Education for sustainable society: Attainments and good practices in Sweden during the United Nations Decade for Education for Sustainable Development (UNDESD). Environ. Dev. Sustain. 2015, 17, 1-21. [CrossRef]

90. Kronlid, D.O.; Öhman, J. An environmental ethical conceptual framework for research on sustainability and environmental education. Environ. Educ. Res. 2013, 19, 21-44. [CrossRef]

91. Öhman, J. Pluralism and criticism in environmental education and education for sustainable development: A practical understanding. Environ. Educ. Res. 2006, 12, 149-163. [CrossRef]

92. Katz, E. The call of the wild. Environ. Ethics 1992, 14, 265-273. [CrossRef]

93. Kopnina, H. Half the earth for people (or more)? Addressing ethical questions in conservation. Biol. Conserv. 2016, 203, 176-185. [CrossRef]

94. Kopnina, H. Wild Animals and Justice: The Case of the Dead Elephant in the Room. J. Int. Wildl. Law Policy 2016, 19, 219-235. [CrossRef]

95. Kopnina, H. The victims of unsustainability: A challenge to Sustainable Development Goals. Int. J. Sustain. Dev. World Ecol. 2016, 23, 113-121. [CrossRef]

96. Kopnina, H. The Lorax Complex: Deep ecology, Ecocentrism and Exclusion. J. Integr. Environ. Sci. 2012, 9, 235-254. [CrossRef]

97. Kopnina, H. Towards Conservational Anthropology: Addressing anthropocentric bias in anthropology. Dialect. Anthropol. 2012, 36, 127-146. [CrossRef]

98. Kopnina, H. Re-Examining Culture/Conservation Conflict: The view of anthropology of conservation through the lens of environmental ethics. J. Integr. Environ. Sci. 2012, 9, 9-25. [CrossRef]

99. Shoreman-Ouimet, E.; Kopnina, H. Reconciling Ecological and Social Justice to Promote Biodiversity Conservation. Biol. Conserv. 2015, 184, 320-326. [CrossRef]

100. Bengtsson, S.L. Aporias, politics of ontology, ethics, and "we"? J. Environ. Educ. 2016, 47, 163-168. [CrossRef]

101. Bonnett, M. Sustainability, the metaphysics of mastery and transcendent nature. In Sustainability: Key Issues; Kopnina, H., Shoreman-Ouimet, E., Eds.; Routledge Earthscan: New York, NY, USA, 2015; pp. 25-39.

102. Huckle, J.; Wals, A.E.J. The UN Decade of Education for Sustainable Development: Business as usual in the end. Environ. Educ. Res. 2015, 21, 491-505. [CrossRef]

103. Lotz-Sisitka, H.; Wals, A.E.J.; Kronlid, D.; McGarry, D. Transformative, transgressive social learning: Rethinking higher education pedagogy in times of systemic global dysfunction. Curr. Opin. Environ. Sustain. 2015, 16, 73-80. [CrossRef]

104. Payne, P.G. The politics of environmental education. Critical inquiry and education for sustainable development. J. Environ. Educ. 2016, 47, 69-76. [CrossRef]

105. Mathews, F. From biodiversity-based conservation to an ethic of bio-proportionality. Biol. Conserv. 2016, 200, 140-148. [CrossRef]

106. Strang, V. Justice for all: Uncomfortable truths-And reconciliation-In human-non-human relations. In Routledge Handbook of Environmental Anthropology; Kopnina, H., Shoreman-Ouimet, E., Eds.; Routledge: New York, NY, USA, 2017; pp. 259-275.

107. Crist, E.; Kopnina, H. Unsettling Anthropocentrism. Dialect. Anthropol. 2014, 38, 387-396. [CrossRef]

108. Kopnina, H. Revisiting the Lorax complex: Deep ecology and biophilia in cross-cultural perspective. Environ. Sociol. 2015, 43, 315-324. [CrossRef]

109. Kopnina, H. Forsaking Nature? Contesting 'Biodiversity' Through Competing Discourses of Sustainability. J. Educ. Sustain. Dev. 2013, 7, 47-59. [CrossRef]

110. Spannring, R. Animals in environmental education research. Environ. Educ. Res. 2016, 23, 63-74. [CrossRef]

111. Waldau, P. Venturing beyond the Tyranny of Small Differences: The Animal Protection Movement, Conservation, and Environmental Education. In Ignoring Nature No More: The Case for Compassionate Conservation; Beckoff, M., Ed.; University of Chicago Press: Chicago, IL, USA, 2013; pp. 27-44. 
112. McDonough, W.; Braungart, M. Cradle to Cradle: Remaking the Way We Make Things; Vintage Books: London, UK, 2002.

113. Webster, K. Hidden Sources: Understanding Natural Systems is the Key to an Evolving and Aspirational ESD. J. Educ. Sustain. Dev. 2007, 1, 37-43. [CrossRef]

114. Kopnina, H.; Blewitt, J. Sustainable Business: Key Issues; Routledge: New York, NY, USA, 2014.

115. Stern, P.C. Toward a coherent theory of environmentally significant behaviour. J. Soc. Issues 2000, 36, 407-424. [CrossRef]

116. Stern, P.C.; Dietz, T. The value basis of environmental concern. J. Soc. Issues 1994, 50, 65-84. [CrossRef]

117. Washington, H.; Taylor, B.; Kopnina, H.; Cryer, P.; Piccolo, J. Why ecocentrism is the key pathway to sustainability. Ecol. Citiz. 2017. Available online: http://www.ecologicalcitizen.net/article.php?t=whyecocentrism-key-pathway-sustainability (accessed on 9 August 2017).

118. Jickling, B.; Wals, A.E.J. Globalization and environmental education: Looking beyond sustainable development. J. Curric. Stud. 2007, 40, 1-21. [CrossRef]

119. Stevenson, R. Tensions and transitions in policy discourse: Recontextualising a decontextualised EE/ESD debate. Environ. Educ. Res. 2006, 12, 277-290. [CrossRef]

120. Chawla, L.; Cushing, D. Education for strategic environmental behaviour. Environ. Educ. Res. 2007, 13, 437-452. [CrossRef]

121. UNESCO; UNEP. The Belgrade Charter-A Global Framework for Environmental Education. Available online: http:/ / unesdoc.unesco.org/images/0015/001534/153446eb.pdf (accessed on 1 July 2017).

122. The Convention on the Protection and Promotion of the Diversity of Cultural Expressions. 2005. Available online: http:/ / en.unesco.org/creativity/convention (accessed on 10 August 2017).

123. Sauvé, L. Currents in environmental education: Mapping a complex and evolving pedagogical field. Can. J. Environ. Educ. 2005, 10, 11-37.

124. Berryman, T.; Sauvé, L. Ruling relationships in sustainable development and education for sustainable development. J. Environ. Educ. 2016, 47, 104-117. [CrossRef]

125. Barth, M.; Rieckmann, M. State of the Art in Research on Higher Education for Sustainable Development. In Routledge Handbook of Higher Education for Sustainable Development; Barth, M., Michelsen, G., Rieckmann, M., Thomas, I., Eds.; Routledge: London, UK, 2016; pp. 100-113.

126. McKeown, R.; Hopkins, C. EE $\neq$ ESD: Defusing the Worry. Environ. Educ. Res. 2003, 9, 117-128. [CrossRef]

127. Aguilar, O.M. Examining the literature to reveal the nature of community EE/ESD programs and research. Environ. Educ. Res. 2016, 1-24. [CrossRef]

128. Huckle, J. Environmental education. In Geographical Education: Reflection and Action; Huckle, J., Ed.; Oxford University Press: Oxford, UK, 1983.

129. Robottom, I. Towards enquiry-based professional development in environmental education. In Environmental Education: Practice and Possibility; Robottom, I., Ed.; Deakin University Press: Geelong, Australian, 1987.

130. Johnson, S. 'Higher education and sustainable development: Paradox and possibility' Book Review. Environ. Educ. Res. 2011, 17, 281-284. [CrossRef]

131. Reid, A.; Scott, W. Researching education and the environment: Retrospect and prospect. Environ. Educ. Res. 2006, 12, 571-587. [CrossRef]

132. Kopnina, H.; Cocis, A. Testing Ecocentric and Anthropocentric Attitudes toward the Sustainable Development (EAATSD) Scale with Bachelor Students. Eur. J. Soc. Anthropol. 2017, 2, 1-12. [CrossRef]

133. Light, A. Compatibilism in political ecology. In Environmental Pragmatism; Light, A., Katz, E., Eds.; Routledge: New York, NY, USA, 1996; pp. 161-184.

134. Vucetich, J.A.; Nelson, M.P. The Infirm Ethical Foundations of Conservation. In Ignoring Nature No More: The Case for Compassionate Conservation; Beckoff, M., Ed.; University of Chicago Press: Chicago, IL, USA, 2013; pp. 9-25.

135. Eckersley, R. The Green State: Rethinking Democracy and Sovereignty; MIT Press: London, UK, 2004.

136. Nemetz, P. Business and Sustainability Challenge: An Integrated Perspective; Routledge: New York, NY, USA, 2013.

137. Hansen, A.; Wethal, U. (Eds.) Emerging Economies and Challenges to Sustainability: Theories, Strategies, Local Realities; Routledge: New York, NY, USA, 2014.

138. Rickinson, M. Reviewing research evidence in environmental education: Some methodological reflections and challenges. Environ. Educ. Res. 2003, 9, 257-271. [CrossRef] 
139. Zint, M. Advancing environmental education program evaluation: Insights from a review of behavioral outcome evaluations. In International Handbook of Research in Environmental Education; Stephenson, B., Brody, M., Dillon, J., Wals, A., Eds.; Routledge: New York, NY, USA, 2012; pp. 298-309.

140. Zint, M. Evaluating education for sustainable development programs. In World Trends on Education for Sustainable Development; Leal Filho, W., Ed.; Peter Lang: Frankfurt, Germany, 2011.

141. Efird, R. Perceiving Nature's Personhood: Anthropological Enhancements to Environmental Education. In Routledge Handbook of Environmental Anthropology; Kopnina, H., Shoreman-Ouimet, E., Eds.; Routledge: New York, NY, USA, 2017; pp. 441-451.

(C) 2017 by the authors. Licensee MDPI, Basel, Switzerland. This article is an open access article distributed under the terms and conditions of the Creative Commons Attribution (CC BY) license (http://creativecommons.org/licenses/by/4.0/). 